\title{
THINKING ABOUT PLACE: RESEARCHING AND READING THE GLOBAL HISTORY OF NURSING
}

\author{
Patricia D'Antonio ${ }^{1}$
}

\begin{abstract}
${ }^{1}$ RN, FAAN, PhD. Associate Professor of Nursing and Associate Director, Barbara Bates Center for the Study of the History of Nursing. University of Pennsylvania School of Nursing. Philadelphia, Unidet States. E-mail: dantonio@nursing.upenn.edu

ABSTRACT: This paper considers place as a category of analysis. As nursing as a practice discipline and the history of nursing as a field of scholarship both enter a more self-consciously global arena and scholars are moving beyond the nation and the nation-state as the primary context for historical inquiry. At the same time, the work of nursing is, has been, and always will be a very private and intimate act. This paper considers two challenges to those interested in exploring how the history of nursing might consider this juxtaposition of the global and the local. The first is conceptual and considers ways to more systematically mine national studies of the history of nursing. The second is structural and explores how we can build a body of scholarship and cadre of scholars that cut across conventional linguistic and cultural boundaries and create a vibrant community of discussion and dialogue.
\end{abstract}

DESCRIPTORS: History of nursing. Nursing theory. Internationality.

\section{PENSANDO ACERCA DEL LUGAR: INVESTIGANDO Y LEYENDO LA HISTORIA GLOBAL DE LA ENFERMERÍA}

RESUMEN: En este estudio se considera el lugar como una categoría de análisis. La enfermería como una disciplina práctica y la historia de la enfermería como un campo de conocimiento. Ambas categorías están situadas en un área mayor de conciencia global, donde los investigadores se desplazan más allá de sus países y estados, estableciendo un contexto primario para la investigación histórica. Al mismo tiempo, el trabajo de la enfermería es, ha sido y siempre será un acto privado e íntimo. Este estudio considera dos retos para los interesados en explorar cómo la historia de la enfermería puede considerar esa yuxtaposición de lo global y lo local. El primer reto es conceptual y considera las maneras de explorar los estudios nacionales de la historia de la enfermería de manera más sistemática. El segundo es estructural y explora cómo podemos construir un corpo de conocimientos y un grupo de investigadores que trasciendan el lenguaje convencional, las barreras culturales y creen una vibrante comunidad de debate y diálogo.

DESCRIPTORES: Historia de la enfermería. Teoria de enfermería. Internacionalidad.

\section{PENSANDO SOBRE O LUGAR: PESQUISANDO E LENDO A HISTÓRIA GLOBAL DA ENFERMAGEM}

RESUMO: Este estudo considera o lugar como uma categoria de análise. A enfermagem como uma disciplina prática e a história da enfermagem como um campo de conhecimento. Ambos se situaram em uma maior área de autoconsciência global e os estudiosos estão se deslocando para além de seus países e estados como contexto primário para a investigação histórica. Ao mesmo tempo, o trabalho da enfermagem é, tem sido e sempre será um ato privado e íntimo. Este estudo considera dois desafios para aqueles interessados em explorar como a história da enfermagem pode considerar esta justaposição do global e do local. O primeiro é conceitual e considera as maneiras de explorar os estudos nacionais da história da enfermagem mais sistematicamente. O segundo é estrutural e explora como podemos construir um corpo de conhecimentos e um quadro de estudiosos que atravessem a linguística convencional, barreiras culturais e criem uma vibrante comunidade de discussão e diálogo.

DESCRITORES: História da enfermagem. Teoria de enfermagem. Internacionalidade. 
In my 1999 article - Revisiting and Rethinking the Rewriting on Nursing History - I argued that the history of nursing might look different if we positioned identity as well as work at the center of our analysis. ${ }^{1}$ If there is one overarching theme in my subsequent work on identity in the history of nursing in the United States it is that nursing allowed women and men to trade work that transformed the care provided in American homes, hospitals, and health care systems for the knowledge that changed their identity, their sense of themselves and their social place. I trust I do justice to the path-breaking work of historians in the 1980s who revitalized the field by considering the implications of gender, class and race to tell a story of nurses and nurses' paid work. In their telling, the history of nursing often seemed one of relative powerlessness inherent in the contradictions of the profession's gendered place in American society and health care. But I have instead turned my focus to nurses and their place in particular families and communities as well as in hospitals and health care systems across the United States. This allowed me to tell a different and perhaps more nuanced story: one about the myriad of ways in which women and men reframed the most traditional of gendered expectations - that of caring for the sick - in ways that allowed them to renegotiate the terms of some of their experiences and to reshape their own sense of worth, value, and power.

But as my research unfolded I found that place mattered. The mighty triumvirate of gender, class, and race combined and came apart in very different ways across a wide range of temporal and social landscapes. In my work, I traveled from the urban northern United States where the idea of formal trained nurses first found a foothold to the much less studied rural south where the nursing of strangers remained unsupported and entangled with that done by poor white and African American domestic servants. I moved from the perspectives of nursing educators committed to the development of the profession to those of practicing clinicians balancing the demands of work and family life. The idea of place as a geographic, political, cultural, and liminal space really mattered to the experiences of nurses and to the development of the profession. ${ }^{2}$

I have situated my work to date within the borders of the United States. But my thoughts now turn to ideas about place as nursing as a practice discipline and the history of nursing as a field of scholarship enters a more self-consciously global arena. I, like many others, have been influenced by calls that ask us to move beyond the nation and the nation-state as the primary object and context for historical inquiry. The idea of place has gone global and, in some respects, has been fractured in calls to consider the global circulation of ideas, peoples, processes, and practices. We already have a sense of how historical attention to international work-force migration patterns is fundamentally altering concepts of power and authority in nursing - concepts which still remain understudied and under-theorized aspects nursing's commitment to cultural competence in global research and practice. Catherine $\mathrm{Choy}^{3}$ and Barbara Brush's ${ }^{4}$ work on Philippine nurse migration to the United States, and Margaret Shkimba and Karen Flynn's ${ }^{5}$ studies of Caribbean nurse migration to Britain and Canada provide examples of theoretically complex and methodologically sophisticated research that helps us understand issues of race and racism in predominately white nursing worlds. As a whole, these scholars argue that although all nurses of color had to contend with racism, not all experienced such racism in precisely the same way. Choy's focuses on individual experience. Her most recent biographical study of Filippino born and trained nurse Ines Cayaban, for example, provides a rich, multi-dimensional portrait of agency and activism as Cayaban and her family navigated through the promise and the perils of their new life in the United States. ${ }^{6}$ Flynn, by contrast, focuses on the state. In her work, she argues that the Canadian authorities, in fact, privileged black nurses from English speaking Commonwealth countries over those from French speaking ones. Her body of work also shows the nuances of both inter- and intra race relations as black and white women's shared identity as nurses sometimes served to mediate their particular experiences of racism and cultural dis-identification. ${ }^{5}$ Place still matters.

Place matters as well in a growing body of historical research that explores the tensions that arose over claims of knowledge, skill, and identity when the east met the west, when the colonized met the colonizer, or when the less developed countries met the more developed ones. Barbara Mortimer and Susan McGann's superbly edited collection of essays in New Directions in the History of Nursing: International Perspectives leads the way as dominant Anglo-European, white, and middle-class orientation of nursing histories yields to the perspectives of those of the West Indies, Mauritus, the Pacific rim, and the former African and South and South-East Asian colonies.? The Anglo-European orientation is not irrelevant. 
Sigrun Hvalvik's study of Bergljot Larsson and the founding of the Norwegian Nursing Association points to the continued importance of the international Anglophone networks of early $20^{\text {th }}$ century nurses. ${ }^{8}$ And indigenous does not mean benign. Helen Sweet and Anne Digby's essay on race, identity and the nursing profession in South Africa uses a strike by Black South African nurses at the Sulenkama mission hospital in 1949 to illustrate how non-white, non-European nurses have always practiced within what Sweet and Digby call a spiral of inequalities that existed even in seemingly benevolent and indigenous institutions. ${ }^{9}$

Exciting and important historical work occurs at this particular nexus. Jonh Watt ${ }^{10}$ and Sonya Grypma's ${ }^{11}$ separate work on the development of modern nursing in China; Madeline Healy's on the establishment of educational systems for nurses in India; ${ }^{12}$ and Anne Marie Rafferty, Diane Solano, ${ }^{13}$ and Margaret Jones' ${ }^{14}$ respective contributions to the experiences of British nurses in their nation's far-flung colonies are but a few examples available in the Anglo-English historical literature. As a group, they show how the history of nursing is particularly well suited to consider issues of transnational and global importance.

But the work of nursing is, has been, and always will be a very private and intimate act. Nursing is often invisible, it is sometimes shaped by contextual forces outside if its control, but it is always performed in a particular place with its own particular imperatives. I remain intrigued by this juxtaposition of the global and the very local: about what ideas about nursing, nurses, and care work transcend national boundaries - what assumptions and practices cut across time, place, and gender - and what ones remain embedded in the context of place: in community norms and local values. This paper considers two challenges to those interested in exploring how the history of nursing might consider this juxtaposition of the global and the local. The first is conceptual: what kinds of new questions might allow us to research and write such histories? The second is structural: how can we build a body of scholarship and cadre of scholars that cut across conventional linguistic and cultural boundaries and create a vibrant community of discussion and dialogue?

\section{NEW RESEARCH QUESTIONS}

Gertje Boschma has published a thoughtful essay about international history in a guest edito- rial in the Nursing History Review. "Good international history," she wrote, "is historical scholarship that contributes to the exploration of diversity in local contexts, helps to unsettle parochial assumptions about nursing and health care, and, most of all, assists us in reaching a deeper understanding of what it means to be different" ${ }^{\prime 15: 9}$

Boschma's definition again underscores the importance of an internationalizing project in nursing's history. It would be one that interrogates the cultural structure of ideas that are all too often taken for granted. It would tell stories that challenge deeply held disciplinary beliefs about how responsibility for the sick is assigned and assumed. And it would situate nurses and nursing in a world that is at least trying to be more attentive to issues of difference and diversity. In the end, I think, such a project would also make us more aware of the fact that diversity is not just about representation, it is also about power. It is about the very real struggle to determine whose voice will be heard when. And, in the collision of ideas about rights and responsibility, it may well be a history of conflicts as well as collaboration.

We have rich histories of nursing in nations across the globe. We have historians mining such histories for what they say about women's roles, professions and professionalism, social welfare policies, and the place of institutional structures in the promotion of health in the well and the alleviation of suffering of the sick. We also have scholars turning to such histories as illustrative of complicated intersections: most often between that of the state, on the one hand, and that of charitable or religious organizations, on the other. As I have noted elsewhere, historians who have studied nursing in countries with more centralized national governments have long argued that interest in interest in and support for nursing's reform initiatives have often been for reasons that have little to do with only ensuring improvements in health care services. ${ }^{16}$ In France, for example, the government of the Third Republic promoted reforms nursing education and practice as part of a policy to diminish the influence of the Roman Catholic Church, in general, and the religious nursing sisterhoods, in particular. ${ }^{17}$ Likewise, the South African state championed the professionalizing aspirations of nursing as a remarkably effective tool to create a stable, bourgeois middle class that might support the policies of the apartheid government. ${ }^{18}$

We are at the point, however, where we need to begin to more systematically pull together 
studies of nursing in individual nation states into a whole to analyze their broader implications. We need international historiographical studies that will synthesize particular groups of international histories of nursing to point to some ideas about how local, regional, and global contexts shaped nursing and nursing practice. There are many ways to do this. But there are two extant models available in the nursing literature. The first, Chan and Wong's study of basic nursing education in China and Hong Kong, considers their countries' educational systems as historically shaped by two global and often competing spheres of nursing influence: that of the United States and that of Great Britain, respectively; and they explore the structural and ideological differences that impact on attempts to develop more unified educational and practice policies. ${ }^{19}$

Cynthia Connolly's work provides a second model. Her focus is on an illness construct, pediatric tuberculosis; and her interest is in the different shapes an international consensus on the need to prevent such a disease in children took in France, Germany, and the United States. There were some differences across these three nation states. But the one constant was nurses: in each place, nurses were the central actors in identifying at-risk children and calling in to play the resources necessary to preserve their health. ${ }^{20}$

\section{GLOBALIZING THE INTERNATIONALI- ZATION PROJECT}

If place matters, then so does language about place. To this end, I do find it useful to carefully differentiate between the terms "international" and "global." I am influenced in this by those who argue that an "international" perspective means situating one's self within a nation and looking out to the rest of the world with traditional nation-state boundaries. A global perspective, on the other hand, means seeing one's self as part of a broader world with more mutable boundaries and one in which one is one, but only one, actor. Some might argue that the difference is semantic, but it has helped me re-think nursing's fundamental commitment - the care of the sick - as transnational. And it has helped me search for those places illustrative of transnational practices. Sylvelyn Hähner-Rombach and I now focus on the ideas, practices, and experiences of the German women of the Diaconate and their religious counterparts in the United States, the German and German-American women of the Lutheran
Deaconate. These women traveled back and forth between Germany and the United States, and they remained in close contact through letters and the structure of the Motherhouse system in which they lived. Conceptually, their history can provide a rare window into the migration of ideas, people and care practices to and from Germany and the United States, and will allow us to explore how ideas, practices, and experiences caring for the sick were shaped by the trans-Atlantic communities in which they existed. As we develop this project we hope to consider questions of fundamental human interest. How do communities cared for their most vulnerable members? How do ideas and practices about caring for the sick migrate back and forth across the Atlantic? What relationships exist between religious convictions and social services when viewed from a transnational perspective? What kinds of ideas and responsibilities about caring for the sick transcend nation-state boundaries? And what kinds are tied tightly to more personal notions of individual identity and political citizenship that shaped both the German and the German-American historical experience? ${ }^{21}$

In another role, that as editor of the Nursing History Review, I also see increasing recognition that the history of nursing provides the ideal vehicle to address what has already been identified as the key methodological challenge to the practice of transnational and global history: how does one consider such global circulations among multiple sites (rather than, as is more customary, those that consider the interactions between two national or regional sites)? Julia Irwin's forthcoming article in the Nursing History Review argues that nurses have always and quite easily crossed national, continental, and cultural borders in their work. She traces the experiences of four early $20^{\text {th }}$ American Red Cross nurses who each worked in many different places in eastern and western Europe and in Russia. She argues that their maternal - child work helped make American nursing a global enterprise. At the same time, these women forged networks and on the ground relationships that assisted the United States in securing its status as a world power. Irwin also takes on some historiographical traditions. She cautions that is would be an oversimplification to cast these particular women as merely, in her evocative phrase, imperialists in progressive clothing. These American nurses put forward a new vision for the role of the United States in the world: one that defined humanitarian engagement and assistance as the proper way for the United States to exercise its influence beyond its borders. ${ }^{22}$ 
But place still matters. Aeleah Soine, in her forthcoming article, also in the Review, uses a transnational perspective to study the collaborative and interrelated work of a generation of early $20^{\text {th }}$ century German, American, and British nurses. These women organized national and international nursing associations in order to realize state registration as a stepping stone to other markers of professional recognition, such as collegiate education, full political citizenship, social welfare, and labor legislation. These women's work both transcended and was confined by the limits of their respective nation-states. They shared an ideological foundation of professionalism, but the potential for global transnational collaboration floundered as their common goals and measures of success became increasingly reliant on the particular laws and customs of individual nation-states. ${ }^{23}$

\section{CROSSING BOUNDARIES}

Place also matters in the reading of the global history of nursing. Here, I define reading as a methodological tool. One reads, in history as in any other scholarly discipline, to discover what is known, what is contested, and what remains to be discovered about the event, object, person, concept, or moment in time of interest. One also reads in history to place one's event, object, person, concept, or moment in time within a particular framework of historical inquiry. Early in the research process, reading extant literature structures the formulation of the initial historical questions that will guide subsequent research. Later in the research process, it guides how one decides not only what data is need but also, and perhaps most importantly, the relative significance of identified data. And finally, careful reading directs the particular generalizations that might be drawn from one's study, and the judgments that one might make about meaning, identity, worth, or work. ${ }^{24}$

As is readily apparent, my perspectives on the shape of global perspectives in the researching and writing of nursing history are constrained by my need to remain within the domain of English language journals and books. There is a large and exceptional body of scholarship that I cannot access and my formulations are weakened by that. One of our most urgent needs is to think about ways to create a place that cut across conventional linguistic and cultural boundaries and create a vibrant community of discussion and dialogue. Shani D'Cruze, Nancy Rose Hunt, Kathleen Canning and Clare Midgley, in their editorial in Gender and History have termed this place the "jagged edge" of more globally oriented research and publication. A place on the "jagged edge" involves creating a new rubric for international conferences: one that allows for both the presentation of international scholarship and the sustained time to work with the language issues, and the debates and dialogues that will yield new understandings of nursing, and that will set the framework for the collaborative manuscripts waiting to be published. ${ }^{25}$ To my mind, it also means creating places that remain true to the editorial processes that underpin assessments of quality in research yet remain responsive to different languages and different ways of knowledge development and dissemination.

It can be done. In 2008, the Nursing History Review published a special section on "Nursing History in Germany: Past, Project, Papers and Prospects," edited by Sylvelyn Hähner-Rombach and Christoph Schweikardt. Many of manuscripts proposed for this section were originally composed in German, and the success of this project depended on two things: the generosity of scholars who maintained the integrity of the editorial peer review process by reading a German language manuscript and writing an English language review for my use; and the generosity of the Institut für Geschichte der Medizin der Robert Bosch Stiftung who financially supported the translation and editing of all German language manuscripts accepted for publication. This was an excellent model. Unfortunately, in terms of material resources necessary, it is not an easily replicable one. Other models that some of my American editorial colleagues use involve referring the author to a commercial translation service (of which there are many), although only a few scholars have the funds to support this. Suggestions to bring an English speaking co-author on board have never, in my experience, worked out well. There is integrity to a particular voice that is necessary to preserve.

But more self-consciously situating place within the process of reading of global nursing history has led me to think about different kinds of alternatives. I no longer, for example, think about place as a physical, social, or cultural reality. Place can also be a virtual space opened to us by the vastness of the internet and exploited by us using new digital technologies. I remain intrigued by the possibilities of networking sites created by Web 2.0 technologies and about the translational support, admittedly still rather simplistic, that might be available to us within such sites. I imagine a 
community of scholars working together within such a site posting with one posting abstracts of recent works and others providing brief translations in multiple languages to bring our scholarship to the widest possible audiences. But I also imagine disciplinary journals, the most traditional medium of knowledge dissemination and debate, no longer assuming audiences that read a finite number of languages and that provide its own place for brief reports of important articles written in their original language.

The researching and reading of nursing's history need to continue mining the richness that a global perspective brings to the development of scholarship in the discipline. But such a perspective is also a point of view. As such it should do what any particular perspective might do. It should allow us to ask and answer new kinds of questions about people and processes that have heretofore been invisible. It should help us write histories, as S. Jay Kleinberg, Eileen Boris, and Vicki Ruiz challenges us, “...in which identity covers multiple dimensions so that one is not merely gendered, or raced, or classed, or abled, but all of these factors combine and refract upon each other in a mezcla (or mixture) of self and society?" ${ }^{26: 4}$ Charles McGaw, for example, brings this perspective to his biography of the late $19^{\text {th }}$ century German-American nurse, Bettina Hofker-Lesser in thinking about how her background and her work for the United States government during the Cuban War of Independence drew its power from her representation of the transnational migration of a very respected German model of nursing. ${ }^{27} \mathrm{~A}$ global perspective, then, enriches our history of nursing whether they take place at the bedsides of our patients or gleaned from the experiences of nurses around the world.

\section{REFERENCES}

1. D'Antonio P. Revisiting and rethinking the rewriting of nursing's history. Bull Hist Med. 1999; 73(3):268-90.

2. D'Antonio P. Introduction. American nursing: neighborhood work and national mission. Baltimore (US): Johns Hopkins University Press; in press.

3. Choy CC. Empire of care: nursing and migration in Filipino American history. Durham (US): Duke University Press; 2003.

4. Brush B. Exchangees or employees? The exchange visitor program and foreign nurse immigration to the United States, 1945-1990. Nurs Hist Rev. 1993; 1: 171-80.
5. Shkimba M, Flynn K. 'In England we did nursing': Caribbean and British nurses in Great Britain and Canada, 1950-70. In: Mortimer B, McGannS, editors. New directions in the history of nursing: International perspectives. London (UK): Routlege; 2005. p. 141-57.

6. Choy CC. Nurses across borders: Foregrounding international migration in nursing history. Nurs Hist Rev. 2010; 18: in press.

7. Mortimer B, McGann S, editors. New directions in the history of nursing: international perspectives. London (UK): Routlege; 2005.

8. Havalvik S. Berglot Larsson (1883-1968), founder and leader of the Norwegian Nursing Association: A case study of the influence of international nursing," In: Mortimer B, McGann S, editors. New directions in the history of nursing: International perspectives. London (UK): Routlege; 2005. p. 40-54.

9. Sweet H, Digby A. Race, identity and the nursing profession in South Africa. In: Mortimer B, McGann $S$, editors. New directions in the history of nursing: International perspectives. London (UK): Routlege; 2005. p. 109-24.

10. WattsJ. Breaking into public service: The development of nursing in modern China, 1870-1949. Nurs Hist Rev. 2004; 12: 67-96.

11. Grypma S. Healing Henan: Canadian nurses at the North China Mission, 1888-1947. Vancouver, CA: University of British Columbia Press; 2008.

12. Healy M. "Seeds that may take root": International aid nurses and projects of professionalism in postindependence India, 1947-1965. Nurs Hist Rev. 2008; 16: 58-90.

13. Rafferty AM, Solano D. The rise and demise of the Colonial Nursing Service: British nurses in the colonies, 1896-1996. Nurs Hist Rev. 2007; (15):147-54.

14. Jones M. Heroines of lonely outposts or tools of the empire? British nurses in Britain's model colony: Ceylon, 1878-1948. Nurs Inq. 2004; 11(3):148-60.

15. Boschma G. Writing international history: What does it mean? Nurs Hist Rev. 2008; 16: 9-13.

16. D'Antonio P. Women, nursing, and baccalaureate education in twentieth century America. J Nurs Scholarsh. 2004; 36(4):379-84.

17. Schultheiss K. Bodies and souls: Politics and the professionalization of nursing in France, 1880-1922. Cambridge, Mass: Harvard University Press; 2001.

18. Marks S. Divided sisterhood: Race, class and gender in the South African nursing profession London: Palgrave Macmillan; 1994.

19. Chan S, Wong F. Development of basic nursing education in China and Hong Kong. J Adv Nurs. 1999; 29(6):1300-7.

20. Connolly C. Pale, poor, and 'pretubercular' children: a history of pediatric antituberculosis efforts in France, Germany, and the United States, 1899-1929. Nurs Inq. 2004; 11 (3):138-47. 
21. D'Antonio P, Hähner-Rombach S. Communities of care: New questions and new methods in the history of the German and German American Diaconate, Agnes Dillon Randolph International Nursing History Conference, University of Virginia; March 2009.

22. Irwin J. Nurses without borders: The history of nursing as American international history. Nurs Hist Rev. [forthcoming 2010].

23. Soine A. "The relation of the nurse to the working world": Professionalization, citizenship, and class in Germany, Great Britain, and the United States before World War I. Nurs Hist Rev 2010; 18: in press.

24. D'Antonio P. Conceptual and methodological issues in historical research. In: Lewenson S, Herrmann E, editors. Capturing nursing history. New York (US): Springer Publishing; 2008. p. 11-23.

25. D'Cruze S, Rose Hunt N, Canning K, Midgley C. Gender on the edge. Gend Hist. 2002; 14(1):1-6.

26. Kleinberg SJ, Boris E, Ruiz VL. Introduction: Narratives, intersections, and dialogues. In: Kleinberg SJ, Boris E, Ruiz VLS, editors. The practice of U.S. women's history: Narratives, intersections, and dialogues. New Brunswick: Rutgers University Press; 2007. p. 4.

27. McGaw C. "The intervention of a friendly power": The transnational migration of women's work and 1898 imperial imagination. J Womens Hist. 2007; 19(3):137-60. 